\title{
減塩・低塩奨油の造り方 (1)
}

\section{直接製造法の濃厚低塩仕込み法}

近年の食生活の変化や人々の健康志向から, 瞫油等の調味料の食塩濃度を低減化することに注目が集まっ ている。また, 奨油の消費が漸減しつつあることから, 新しい調味料製品の開発に期待が高まっている。食 塩を上手に使いこなしてきたわが国の発酵調味料製造技術のなかでは，これまでにも食塩の使用量を低減化 する技術が研究されてきている。本解説では，長年の酱油醸造技術に携わってこられた著者のこ経験と知識 に基づいて, 減塩・低塩奨油の醸造についての研究ならびに技術開発を網羅的に解説いただくとともに, こ れからの調味料製造技術の展望について述べていただいた。

\section{中 台 忠 信}

\section{はじめに}

2010 年版の「日本人の食事摂取基準」における, 食塩摂取の目標量は成人男性が $9 \mathrm{~g}$ 未満, 成人女性が $7.5 \mathrm{~g}$ 未満と, 2005 年のそれぞれ $10 \mathrm{~g}$ と $8 \mathrm{~g}$ 未満に比べ てさらに少なくなっている。

2001 年における日本人の 1 日当たりの食塩摂取量 の平均值は男性が $12.9 \mathrm{~g}$, 女性が $11.5 \mathrm{~g}$ であるが, 2009 年には男性が $11.6 \mathrm{~g}$, 女性が $9.9 \mathrm{~g}$ と減少している が，前述の目標には今一歩である (第 1 図) ${ }^{1)}$ 。

1975 年の食品からの食塩の 1 日当たりの摂取量は, その他の調味料から $1.2 \mathrm{~g}$, 酱油から $3.4 \mathrm{~g}$ であったが, 2005 年にはその他の調味料が $1.9 \mathrm{~g}$ と増加しているが, 奨油からは $2.5 \mathrm{~g}$ と $0.9 \mathrm{~g}$ 減少しているが, 未だ奨油か らは第 1 位であるので, 減少させる必要があると考え られる(第 2 図 ${ }^{2)}$ 。

ニューヨーク市は 2010 年に, レストランおよびス ーパーマーケットで販売される食品（ソースおよび調 味料を含む）に含まれる食塩を $25 \%$ 削減する 5 力年 計画を発表している。この動きが全米に拡大すると予 測すると, 米国には減塩, 低塩奨油を輸出する方がよ いと考えられる。
欧州議会は栄養表示の一環として, 食塩量の表示義 務を 2011 年 7 月 6 日に承認しているので, EUにお いて, 減塩, 低塩奨油の伸びる可能性があると考えら れる。

1968 年の市販の代表的な 4 銘柄の濃口と淡口酱油

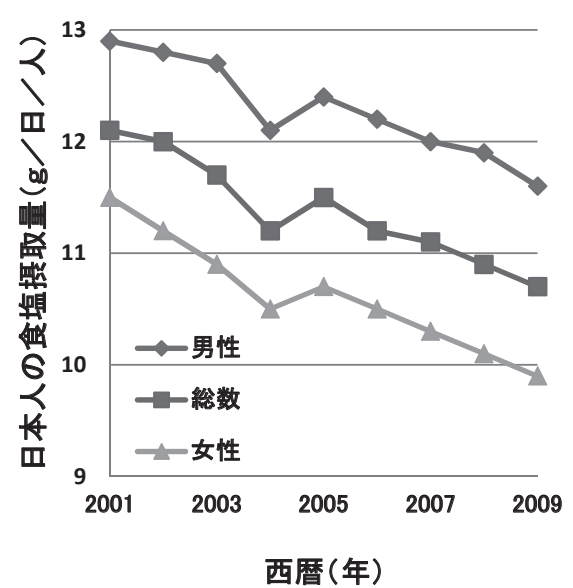

第 1 図 2009 年の日本人の食塩摂取量の男性 11.6 . 女性 $9.9 \mathrm{~g} /$ 日 / 人と目標に今一歩

Production Method of Reduced Salt and Low Salt Soy Sauce (1)

High Nitrogen and Low Salt Fermentation Method in Direct Production Method

Tadanobu Nakadai (Japan Soy Sauce Technology Center) 


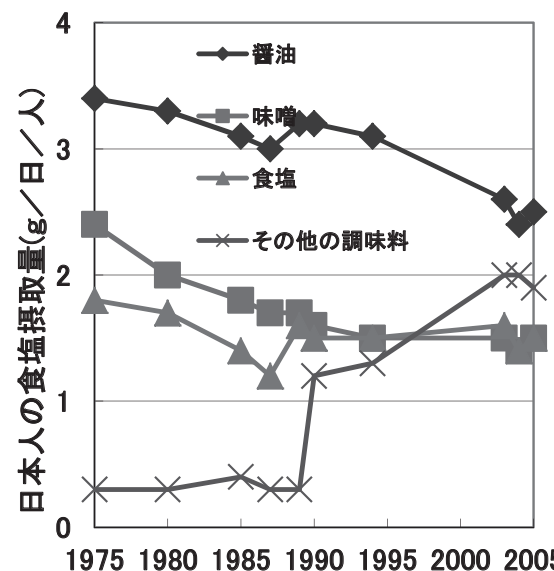

西暦(年)

第 2 図 日本人の食塩摂取量の変動

における食塩濃度の平均值はそれぞれ $18.15 \%$ と 19.99 \%であるが，2010 年にはそれぞれ 16.56\%と 18.67\% と年々減少している (第3 図) ${ }^{3)}$

減塩奨油とは食塩が 9 重量％（w/w）以下である ので, 比重を 1.17 とすると, 食塩が 10.53 容量\%（w/ v）以下のものである。

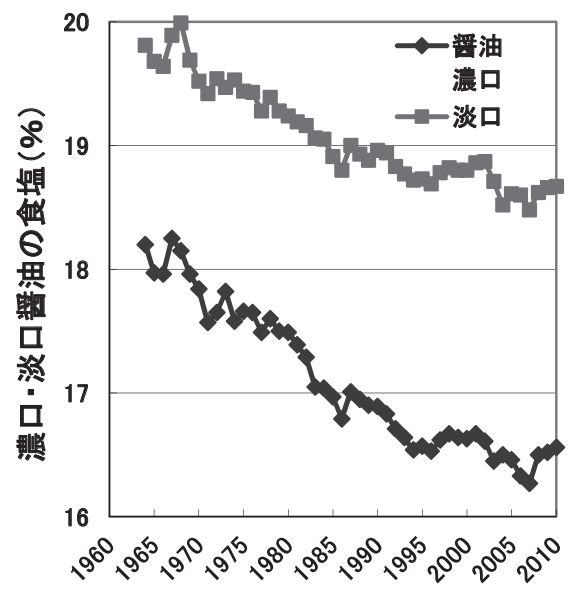

西暦(年)

第 3 図 濃口・淡口奨油の低塩化
低塩奨油とは食塩が滰油業界が定める通常酱油の $80 \%$ 以下〜 $50 \%$ 以上のものであり, 一例として, 濃 口滰油の低塩槒油とは食塩 9 ～ 14 容量\%（w/v）の ものである。

奨油からの食塩の摂取量を低減するためには, 減塩, 低塩奨油の消費を増加させることが有効であるので, その製造方法について，今回は直接製造法の濃厚低塩 仕込み法について文献をまとめる。

\section{1．伸びる減塩奨油と伸び悩む低塩奨油}

JASの格付数量（出荷数量％）で見ると, 減塩奨 油は 1987 年の $0.93 \%$ から, 1996 年には $1.43 \%$ まで伸 びているが，低塩奨油は 1987 年の $1.42 \%$ から， 1996 年には $0.82 \%$ にまで減少している ${ }^{4)}$

出荷数量割合で見ると, 減塩奨油は 1999 年の 1.21 \%から，2009 年の $1.63 \%$ にまで伸びているが，低塩 奨油は 2002 年の $0.78 \%$ から, 2009 年の $0.77 \%$ とほほ 横ばいになり，伸び悩んでいる（第 4 図） ${ }^{3)}$ 。減塩奨 油の出荷割合は 2009 年でまだ $1.6 \%$ と少ないので, 健 康志向，味覚の低塩化嗜好から，これからも伸びる余 地は十分あると考えられる。

\section{2. 減塩・低塩奨油の製造法}

（1）減塩奨油の製造法の 2 極化

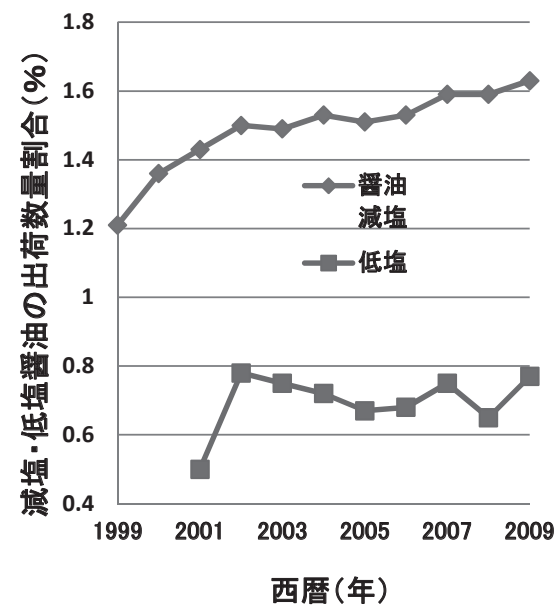

第 4 図 出荷数量割合で見る伸びる減塩奨油と伸び 悩声低塩奨油

醸 協 $(2012)$ 
減塩奨油の製造法には，高コストの一度できあがっ た通常の奨油を脱塩する間接製造法と低コストの直接 製造法に 2 極化している (第 1 表)。

（2） 1989 年頃の減塩・低塩奨油の製造法における多 い濃厚・低塩仕込み法

1989 年頃の減塩, 低塩啰油の製造法において, 濃 厚仕込み法はそれぞれ 35 と $23 \%$, 低塩仕込み法はそ れぞれ 32 と $13 \%$ と多い。なお, 最近の傾向はデー夕 がないので，不明であるが，イオン交換膜法が多くな っていると考えられる ${ }^{5)}$ 。

\section{I . 直接製造法}

最初に, コストの安い, 直接製造法の中の低塩仕込 み法について述べる。

\section{1. 低塩仕込み・減塩・低塩唒油の耐塩性微生物 污染の危険性}

（1）低塩仕込みによる酸敗とグルタミン酸の減少

1）奨油趜の $13 \%$ 食塩水仕込み（最終約 $5.2 \%$ )
酱油麹を 2.5 倍量の $13 \%$ 食塩水で仕込むことにより， 最終約 $5.2 \%$ の食塩となるが, 仕込み温度 $30,35,40$ ${ }^{\circ} \mathrm{C}$ 全てにおいて, pH が 4.35 以下へと低下し酸敗とグ ルタミン酸の減少が扔こる。な拀, 仕込み温度が 30 ${ }^{\circ} \mathrm{C}$ に比べて， $40^{\circ} \mathrm{C}$ 高い方が酸敗しやすく，これは高 温性の乳酸菌が污染するためと考えられる ${ }^{6)}$ 。なお, 常法の奨油は滰油趜を $25 \%$ 食塩水, 約 1.6 倍量により 仕込むことにより，最終約 17\%の食塩となる。

2）奨油麹の $18 \%$ 食塩水仕込み（最終約 $6.2 \%$ )

奨油麦甸の 2.9 倍量の $18 \%$ 食塩水により仕込むことに より, 最終約 $6.2 \%$ の食塩となるが, $35^{\circ} \mathrm{C}$ に比べて, $45^{\circ} \mathrm{C}$ の高温仕込みの方が $\mathrm{pH} 4.55$ とより酸敗し, グル タミン酸の減少が $40^{\circ} \mathrm{C}$ と $45^{\circ} \mathrm{C}$ に認められる。なお, $35^{\circ} \mathrm{C}$ 仕込みの場合は酸敗とグルタミン酸の減少は 60 日間認められない ${ }^{6)}$ 。

（2）低塩下に扔ける耐塩性乳酸桿菌 (Lactobacillus) の生育

1）食塩 $14 \%$ 以下による L. rennini の生育 食塩 $14 \%$ 以下により, 奨油諸味から分離される

第 1 表 減塩・低塩奨油の製造法の 2 極化

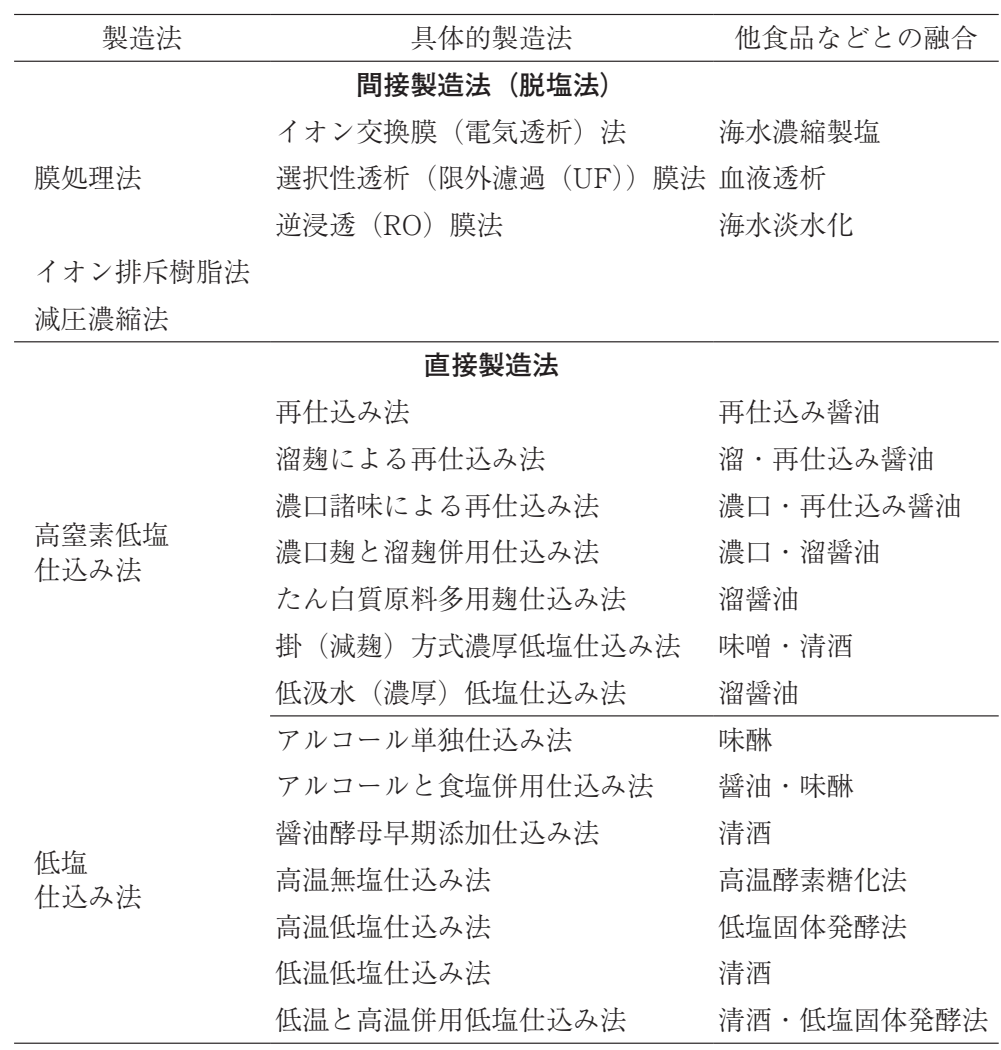


Lactobacillus rennini は生育できる ${ }^{7)}$ 。さらに，変敗 減塩奨油から分離されるL. rennini は食塩 $7.5 \sim 10$ \%以下で生育できる。従って, 前述 1-（1）の酸敗と グルタミン酸の減少はL. rennini の污染によると考 えられる ${ }^{8)}$ 。

2）L. alimentarius の食塩 $16 \%$ 以下による生育

7 日後の GYP 培地において, 変敗減塩奨油から分 離されるL. alimentarius は食塩 $16 \%$ 以下により, 生 育できる ${ }^{9)}$ 。

3）L. coryniformis 近縁菌の食塩 $15 \%$ 以下による 生育

7 日後の $20 \%$ 奨油麦淗汁培地において, 諸味, 生奨油 から分離されるL. coryniformis 近縁菌は食塩 15\%以 下により，生育できる ${ }^{10)}$ 。なお，最近の $16 \mathrm{~S} \mathrm{rDNA}$ 解 析と系統樹より，本菌は L. rennini と考えられる ${ }^{8)}$ 。

(3) 減塩酱油における耐塩性乳酸桿菌の生育

1) L. alimentarius $の$ 生育

$30^{\circ} \mathrm{C}$ の全窒素 $1.61 \%$, 食塩 $9.02 \%, \mathrm{pH} 4.94$ の減塩 奨油において，L. alimentarius は生育できる ${ }^{9)}$ 。なお， 本菌の分類は古典的な分類なので，最近の遺伝子レ心゙ ルの分類ではL. rennini の可能性もあると考えられ る。

\section{2）L. coryniformis 近縁菌の生育}

$32^{\circ} \mathrm{C}$ の全窒素 $1.55 \%$, 食塩 $9.0 \%$, アルコール $3.7 \%$, pH4.80 の減塩酱油において, L. coryniformis 近縁菌 は生育できる ${ }^{10)}$ 。

3）L. plantarum 近縁菌の生育

初発菌数 $10^{3}$ および $10^{7}$ 個 $/ \mathrm{m} l$ で, $30^{\circ} \mathrm{C}$ の全窒素 $1.4 \%, p H 5.0$, 食塩 $12 \%$ 以下の減塩・低塩酱油におい て, L. plantarum 近縁菌は生育できる ${ }^{11)}$ 。なお，本 菌の分類は古典的な分類なので, 最近の遺伝子レベル の分類では L. rennini の可能性もあると考えられる。

（4）濃縮つゆに打けるL. coryniformis 近縁菌の生 育

$32^{\circ} \mathrm{C}$ の食塩 $12.3 \%$ ，アルコール $0.6 \%$ 以下の濃縮つ ゆに拈いて, グルタミン酸を脱炭酸するL. coryniformis 近縁菌は生育できる。なお，この濃縮つゆの 場合, 食塩が $12.3 \%$ で，アルコールが $2.6 \%$ 存在す ると，本菌は生育できない ${ }^{12)}$ 。

（5）L. fructiovorans の低塩による生育

前述 1-（2）～（4）の耐塩性乳酸桿菌はホモ乳酸発 酵型であり, グルタミン酸, アスパラギン酸から炭酸
ガスを発生するが，L. fructiovorans はへテロ型であ り, グルコースから炭酸ガスを発生し, ストレートつ ゆ, のり佃煮, 加工味増などを変敗させる。この $L$. fructiovorans はトマトジュース培地に扔いて, 食塩 9 \%により，生育できる ${ }^{13)}$ 。

（6）腸球菌 Enterococcus faecium の低塩による生育 腸球菌 E. faecium は27 日後の槒油諸味において, 食塩 $12 \%$ 以下により，生育できる。な抏，本菌によ るチラミンの生成は食塩 $7 \%$ 以下で生成される ${ }^{14)}$ 。

（7）比較的耐塩性の乳酸球菌 Streptococcus faecalis の低食塩による生育

1）S. faecalis の食塩 $10 （ \mathrm{w} / \mathrm{v} ） \%$ 以下による生育 比較的耐塩性の乳酸球菌 S. faecalis は食塩 10 (w/ v）\%以下により, 生育できる ${ }^{15)}$ 。

2）乳酸球菌 S. faecalis の食塩 $13 \%$ 以下による生育 奨油添加培地において, 比較的耐塩性の乳酸球菌 S. faecalis は食塩 $13 \%$ 以下により, 生育できる。従 って, 榇油中には本菌の耐塩性を増強する成分が存在 すると考えられる ${ }^{15)}$

3）味増浸出液 $5 \%$ 添加培地に打ける乳酸球菌 $S$. faecalis の生育

味増浸出液 5\%寒天培地において, 比較的耐塩性の 乳酸球菌 S. faecalis は食塩 $15 \%$ 以下により, 生育で きる。従って, 味噌中にも本菌の耐塩性を増強する成 分が存在すると考えられる ${ }^{16)}$ 。

（8）高食塩に馴養培養した乳酸球菌の生育

高食塩に馴養培養した耐塩性・好塩性乳酸球菌は食 塩 $15 \%$ 以下により生育できるので, 高食塩の環境に 曝された滰油工場においては, これらの乳酸球菌が常 在化しており，低塩仕込みを行う際，本菌が生育する 危険性が高くなると考えられる ${ }^{17)}$ 。なお, 乳酸桿菌 の L.rennini, L.fructiovorans は製造設備や工場床で 検出されている ${ }^{8)}$ 。

（9）耐塩性の強い Micrococcace 科細菌の生育

味増・奨油醸造工程中より分離する耐塩性の強い Micrococcace 科細菌は食塩 $14 \%$ 以下により, 生育で きる。なお，合成培地において, Micrococcus varians Mc- 4, M.conglomeratus Mc-132, Tetragenococcus halophilus Pe14 は最適生育食塩濃度がそれぞれ，6，6，8\% であるので，耐塩性というよりは好塩性といえる ${ }^{18)}$

（10）奨油乳酸菌 T.halophilus の低塩による過剩な 生育 
1）味増浸出液培地における槒油乳酸菌の過剩な生育

味噌浸出液 $5 \%$ 寒天培地において, 新油乳酸菌は食 塩 0.5 〜 $5 \%$ にり, 過剩に生育する ${ }^{16)}$ 。

2）奨油添加培地における奨油乳酸菌の過剩な生育 全窒素として $0.04 \%$ 奨油を添加する培地において， 奨油乳酸菌は食塩 $18 \%$ に比べて, 食塩 7\%により過剩 に生育し, 乳酸発酵過多となるので注意しなくてはな らない。さらに, 野生のアミンを生成する悪玉滰油乳 酸菌の旺盛な生育の危険性の確率も高くなると考えら れる。なお, 本培地において奨油乳酸菌は最適生育食 塩濃度が $7 \%$ であので, 耐塩性というよりは好塩性 といえる ${ }^{15)}$ 。

\section{2. 高窒素低塩仕込みの腐造しない理由}

\section{(1) 高窒素低塩仕込みによる減塩奨油の製造}

高窒素 $2.4 \%$, 低食塩 $13.0 \%$ の高窒素低塩仕込みを 行い, 得られる生奨油を規格調整することにより, 全 窒素 $1.6 \%$, 食塩 $8.7 \%$ 減塩奨油を製造できる。

(2) 減塩・低塩奨油の高い水分活性 $(\mathrm{A} w)$

本醸造, 特級の濃口奨油の $\mathrm{A} w 0.830$ に比べて, 減 塩奨油の $\mathrm{A} w$ は 0.887 と 0.057 , 低塩奨油の $\mathrm{A} w$ は 0.860 と 0.03 高くなる ${ }^{19)}$ 。

\section{（3） A w の上昇による耐塩性乳酸菌の生育}

\section{1) S. faecalis · Pediococcus acidilactici の生育}

比較的耐塩性の S. faecalis は A $w 0.935$ 以上（食塩 $10 \%$ 相当), P. acidilactici は A w 0.860 以上（食塩 18 \%相当）により, 生育できるので, 低塩仕込みの場合 に, これらの菌が污染する可能性がある ${ }^{15)}$

2）奨油乳酸菌の過剩な生育

槒油乳酸菌は $\mathrm{A} w 0.96$ により, 過剩に生育できる ${ }^{15)}$ (4) 奨油の食塩濃度と $\mathrm{A} w$ 間の $1 \%$ 有意の相関関係 食塩濃度の異なる減塩奨油（全窒素 1.55\%）に加塩 を行い得られる酱油 I（食塩10\%, $n=6$ ）とII（食 塩 $11 \%, n=5 ） に$ に拈いて, 食塩濃度と $\mathrm{A} w$ 間にはそ れぞれ 0.990 と 0.993 の $1 \%$ 有意の負の相関関係があ る。奨油 I とIIに拈ける回帰式はそれぞれ，y= $-0.0070 \mathrm{x}+0.9267, \mathrm{y}=-0.0082 \mathrm{x}+0.9451$ である ${ }^{15)}$ 。

(5) 溜㽜油の全窒素濃度と $\mathrm{A} w$ 間の相関関係

溜奨油 $(n=9)$ においても, 全窒素濃度と $\mathrm{A} w$ 間 には 0.988 の $1 \%$ 有意の負の相関関係がある。回帰式 は $\mathrm{y}=-0.043 \mathrm{x}+0.9228$ である ${ }^{15)}$ 。

（6）食塩 1\%の増加による A $w 0.007$ の低下
食塩水 $(n=6)$ において, 食塩 $1 \%$ の増加により, $\mathrm{A} w$ は 0.007 低下する。な拉, 両者間には 0.989 の 1 \%有意の負の相関関係があり, 回帰式は $\mathrm{y}=-0.0076 \mathrm{x}$ +1.0123 である ${ }^{15)}$ 。

（7）溜奨油における全窒素の増加による $\mathrm{A} w$ の低下 溜酱油 $(n=8)$ において, 全窒素 $1.0 \%$ 増加により, $\mathrm{A} w$ は 0.043 低下する。なお，両者間には 0.996 の 1 $\%$ 有意の負の相関関係があり, 回帰式は $\mathrm{y}=-0.0428 \mathrm{x}$ +0.0324 である ${ }^{15)}$ 。

（8）高窒素低塩仕込みの腐造しない理由

低塩仕込みにおいて, 通常の諸味の仕込み食塩を $17 \%$ とすると， $13 \%$ と $4 \%$ 食塩を低下させると, $\mathrm{A} w$ が 0.028 上昇するので, 全窒素を $0.65 \%$ 増加させるこ とにより，A $w$ の上昇分を相殺できる。つまり食塩を $4 \%$ 減少させ, $13.0 \%$ の低塩仕込みにする場合, 通常 の諸味の全窒素を $1.75 \%$ とすると, 全窒素を $0.65 \%$ 増 加させて, $2.4 \%$ にすることより, 通常の生酱油と 同一の $\mathrm{A} w$ となり, これが, 高窒素低塩仕込久が腐 造しない理由になると考えられる。

\section{3. 再仕込み法}

\section{（1）高窒素低塩仕込み法の問題点}

高窒素低塩仕込み法により減塩奨油を製造する場合 に最も重要なことは, どのようにして諸味の窒素を高 くするかである。高窒素仕込みのために, 得られる減 塩滰油の色沢安定性が悪くなり, さらにほとんどの高 窒素低塩仕込み法は諸味が硬くなり, 仕込み・諸味擋 拌・汲出に困難を伴う問題点がある。しかし, 再仕込 み法のみはこの諸味が硬くなる問題点はない。

（2）再仕込み法による減塩奨油の製造

再仕込み法により, 全窒素 $2.5 \%$, 食塩 $13.4 \%$ の生 奨油を製造し, これから全窒素 $1.55 \%$, 食塩 $8.2 \%$ の 滅塩奨油を製造することができる ${ }^{20)}$

（3）再仕込み法の改善

再仕込み法により, 全窒素 $2.5 \%$, 食塩 $14 \%$ の生奨 油から減塩㽜油を製造する際, 仕込みに使用する生滰 油が低 $\mathrm{pH}$ で緩衝能が強いために, 再仕込み法の諸味 は低 $\mathrm{pH}$ 経過を辿り，アルカリプロテイナーゼ，グル タミナーゼが十分作用できないので, 窒素利用率やグ ルタミン酸/全窒素の低下が起こる。

1）仕込み用生奨油を $\mathrm{pH} 5.50$ に調整することによ る分解率の低下の少ない再仕込み奨油から減塩 
奨油の製造

再仕込み法において, 仕込み用生奨油を水酸化ナト リウムで pH5.50 に調整することにより，分解率の低 下の少ない全窒素 $2.62 \%$ ・食塩 $17.86 \%$ の再仕込み生 奨油から全窒素 $1.25 \%$ ・食塩 $8.44 \%$ の減塩槒油を製造 できる ${ }^{21)}$

2）仕込み用生槒油の pH6.50に調整することによ るグルタミン酸の低下の少ない再仕込み奨油の 製造

仕込み用生奨油を炭酸ナトリウムで $\mathrm{pH} 6.50$ に調整 して仕込みを行うことにより，窒素利用率に相当する 諸味消化度やグルタミン酸／全窒素，アルコール発酵 がよい再仕込み酱油から減塩奨油を製造できる。なお， 仕込み用生奨油の $\mathrm{pH}$ を 7 にまで中和することにより， 乳酸発酵は改善されるが，アルコール発酵が悪くなり， 生㽜油の中和の際にアンモニア臭もするので避けなく てはならない。

\section{4. 溜埸による再仕込み法 (再仕込み酱油と溜酱油の融合)}

最近は新商品奨油の開発が皆無であるといっても過 言でない。新商品開発のための 1 つのアイデアとして は，各種奨油を融合（フュージョン）させることであ る。再仕込み法には前述 3-（3）の欠点があるので, これと溜奨油を融合させることにより，この欠点を改 善できると考えられる。つまり，前述 3-（3）の生奨 油の $\mathrm{pH}$ を上昇させるためには, $\mathrm{pH}$ 調整剤を使用し なくてはならないが, 脱脂大豆多用麹の溜麦匊の特徽で ある出麹 $\mathrm{pH}$ の高さを利用し, 諸味の $\mathrm{pH}$ を高く推移 させることにより，窒素利用率・グルタミン酸生成の 改善ができると考えられる。脱脂大豆多用麹は持ち込 みの窒素が多いので, 再仕込み用の濃口生滰油の使用 量を低減できるので，さらに，諸味 $\mathrm{pH}$ を高めに推移 できる。な㧍，脱脂大豆の使用割合と出錮 $\mathrm{pH}$ と奨油 の全窒素との間にはそれぞれ 0.990 と 0.999 の 1\%有 意の正の相関関係がある。

\section{5. 濃口諸味による再仕込み法 （濃口醤油と再仕込み酱油の融合）}

奨油麹と $24 \%$ 食塩水 $5: 7$ の濃口諸味へ 63 日後に滰 油と槒油麦甸 5:7 を最終仕込み量の $50 \%$ 追加添加するこ とにより，全窒素 $2.41 \%$ ・食塩 $14.65 \%$ の生奨油から
全窒素 1.58\%・食塩 9.61\%の減塩奨油を製造できる。 従って, これは再仕込み法に打いて, 分解が進み, 柔 らかくなった濃口諸味を生滰油の代わりに使用するこ とになるので，濃口㖶油と再仕込久槒油の融合と考え られる ${ }^{22)}$ 。

\section{6. 濃口麹と溜麹併用仕込み法 (濃口奨油と溜酱油の融合)}

（1）溜麹の多使用による最終諸味粘度の低下

奨油鈿に対して溜趜を多く使用することにより，全 窒素 $2.35 \%$ 当たりの最終諸味粘度は低下し, 特に溜麹 を元 $\mathrm{k} l$ 当たり $30 \%$ 以上使用すると急激に諸味粘度が 低下する。

（2）溜趜の使用によるアルコールの高生成

奨油粩に対して溜趜を元 $\mathrm{k} l$ 当たり $15 \%$ 使用するこ とにより，アルコールは高生成する。なお，溜鈿の使 用量が $30 \%$ 以上になると, 持込みのグルコースが少 なくなるので，急激にアルコール発酵が悪くなる。従 って, 諸味粘度とアルコール発酵を考慮して, 奨油麹 に対する溜趜の使用量は $20 \%$ が適当と考えられる。

（3）奨油趜 79\%に溜趜 21\%の併用による減塩奨油の 製造

元 $\mathrm{k} l$ 当たり奨油麹 79\%に溜趜（散麹 85:15）21\% を併用して，汲水を 10.2 水，純食塩を $193 \mathrm{~kg} /$ 元 $\mathrm{k} l$ 使用することにより，全窒素 $2.288 \%$, 食塩 $13.8 \%$ の 生眢油が得られ，これから全窒素 $1.576 \%$ ，食塩 9.35 \%の減塩滰油ができる。なお，後述 7-（4）のように, 溜麹に使用する小麦は蒸煮大豆の表面を被覆し, 污染 が少ない散麹とするために，常法の炒謷割砕小麦をさ らにターボミルなどで粉末化する。

\section{7. たん白質原料多用麹仕込み法}

(1) 脱脂大豆と小麦の原料配合 61:39による減塩濃 厚奨油の製造

少謷割砕小麦 / 膨化変性脱脂大豆 ${ }^{23} 0.8$ (処理前 $\mathrm{w} /$ $\mathrm{w} \%$ ・原料配合 61:39）以下により, 諸味粘度が 47P 以下の諸味が得られ，これから全窒素約 $2.47 \%$, 食塩 約 $13.9 \%$ の減塩濃厚奨油が得られる。なお，処理前の 脱脂大豆 $860 \mathrm{~g}$ の脱脂大豆多用麹を $20 \%$ 食塩水 $2.1 l$ で 仕込みを行う。最適の小麦/脱脂大豆の比率はアルコ ール生成量の最も高い 0.6 が官能的にも優れている (第 5 図)。 
（2）脱脂大豆 70\%の大豆多用瞵による低塩滰油の製造

脱脂大豆を $70 \%$ 使用する大豆多用敖により，全窒 素 $1.96 \%$, 食塩 $17.0 \%$ の生槒油を得て, これから全窒 素 $1.50 \%$ ・食塩 $13.0 \%$ の低塩奨油を製造できる。さら に，大豆多用趜を低汲水低塩仕込みにすることにより， 諸味は硬くなるが，減塩奨油も製造できる ${ }^{20)}$ 。

（3）脱脂大豆 $62 \%$ の大豆多用哮による減塩奨油の製造 脱脂大豆を $62 \%$ 使用した大豆多用耧を 10.5 水, 純 食塩が $197.5 \mathrm{~kg} /$ 元 $\mathrm{k} l$ 仕込みをすることにより, 全窒 素 $2.176 \%$, 食塩 $13.73 \%$ の生奨油を得て, これから全 窒素 $1.582 \%$ ，食塩 $9.9 \%$ の減塩奨油を製造できる。な お，汲水を 0.5 水少なくする 10 水仕込みの諸味は特 に硬くなるので，注意しなくてはならない。

（4）大豆多用錮による細菌污染の増加

脱脂大豆を $70 \%$ 以上使用する大豆多用麹により， 奨油錮の細菌污染は増加するので, 注意しなくてはな らない ${ }^{24)}$ 。

（5）大豆多用敖の被覆に必要な 30 メッシュ篩下の炒 謷割砕小麦粉

脱脂大豆多用麦匊において, 細菌污染を低減するため には, 脱脂大豆を $70 \%$ 使用の場合, 蒸煮大豆を被覆 するのに必要な 30 メッシュ穊下の炒謷割砕小麦粉は $83 \%$ となるので, 炒謷割砕小麦の粒度を細かくする必 要がある ${ }^{25)}$ 。

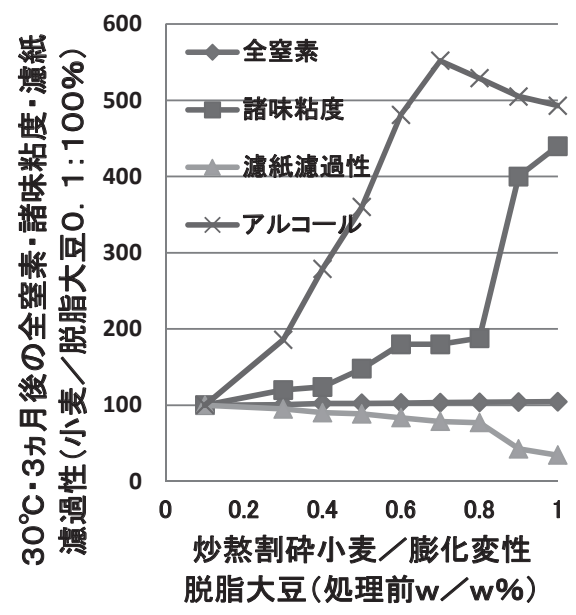

第 5 図 炒謷割砕小麦と膨化変性脱脂を原料とした 減塩濃厚奨油の性質

\section{8. 掛（減麹）方式濃厚低塩仕込み法}

（1）未製趜膨化変性脱脂大豆の減麦法による減塩濃 厚奨油の製造

未製敖膨化変性脱脂大豆 ${ }^{23)}$ を掛原料とする減麹法

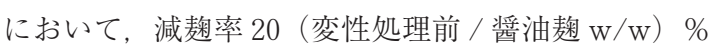
以下により, 諸味粘度 $60 \mathrm{P}$ 以下の諸味が得られ, こ れより全窒素約 $2.5 \%$, 食塩約 $13.3 \%$ の減塩濃厚奨油 が得られる。なお，奨油麹元 $1 l$ に膨化変性脱脂大豆 を加え, $19.5 \%$ 食塩水 $1.2 l$ で仕込みを行う（第 6 図）。

（2）減懒法に打けるグルタミン酸の低生成とピログ ルタミン酸の高生成

原料配合 68.4:31.6 の脱脂大豆多用麹を 10.1 水, 純 食塩 $199 \mathrm{~kg} /$ 元 $\mathrm{k} l$ 仕込みによる全麹法に比べて, 未 製鳌の膨化変性脱脂大豆 ${ }^{23)}$ を製麹原料に対して 20.8 \%（減䡘率）使用する減鈿法（最終原料配合は 63:37）に拈いて，グルタミナーゼ不足により，グル タミン酸/全窒素が低く, 逆にピログルタミン酸/全 窒素は高くなる。従って, 減麹法においては, 不足す るグルタミナーゼを添加しなくてはならない。

（3）掛原料として膨化変性脱脂大豆の使用

未製錮の掛原料として, 膨化変性丸大豆に比べて膨 化変性脱脂大豆を $92 \mathrm{~kg} /$ 元 $\mathrm{k} l$ （減贅率 $17 \%$ ）を 10.8 水, 純食塩 $217 \mathrm{~kg} /$ 元 $\mathrm{k} l$ の仕込みにより, 全窒素 $2.196 \%$, 食塩 $15.28 \%$ の生酱油を得て, これより全窒

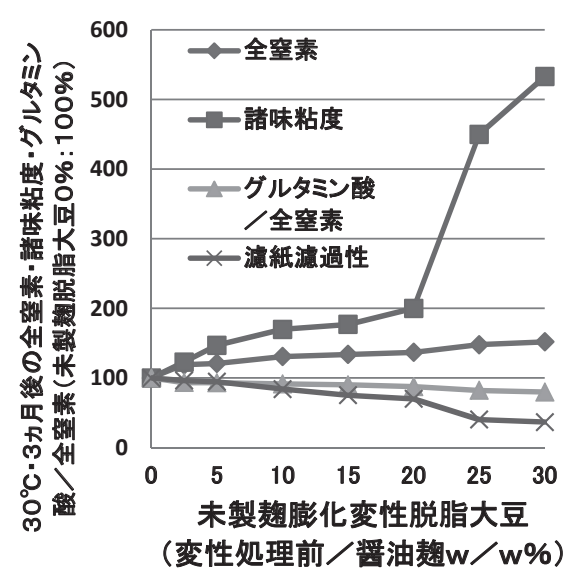

第 6 図未製麹膨化変性脱脂大豆の減责率 $20(\mathrm{w} / \mathrm{w})$ \%以下による減塩濃厚奨油 
素 $1.576 \%$, 食塩 $10.7 \%$ の低塩滰油が得られる。しか し, 減塩槒油とは食塩が $10.53 \%$ 以下であるので, 純 食塩の使用量を下げなくてはならない。なお，膨化丸 大豆は窒素含量が少ないので，窒素を高めるためには， $123 \mathrm{~kg} /$ 元 $\mathrm{k} l$ と多く使用し, 減麦率は $23.4 \%$ となり, 得られる膨化丸大豆の場合の最終諸味粘度も膨化脱脂 大豆の $34 \mathrm{P} に$ 比べて，44P と高くなる欠点がある。従 って, 掛原料としては丸大豆より, 窒素含量の高い脱 脂大豆の方がよい。

（4）脱脂大豆と小麦の同時エクストルーダー処理の 減鈿法による高窒素低塩奨油の製造

脱脂大豆と小麦の粉末を $60: 40$ に混合し同時にエク ストルーダー処理し常法の減趜法（減趜率 $50 \%$ ）に より, 全窒素 $2.18 \%$, 食塩 $14.68 \%$ の高窒素低塩奨油 が得られる。なお，全麹法により, グルタミン酸/全 窒素の高い全窒素 $2.18 \%$, 食塩 $14.91 \%$ 高窒素低塩 酱油が得られる ${ }^{26)}$ 。

（5）掛原料として小麦グルテンの使用

未製敖の掛原料として，窒素含量の高い小麦グルテ ンを $76 \mathrm{~kg} /$ 元 $\mathrm{k} l$ （減贅率 $13 \%$ ）を 11 水, 純食塩 $213 \mathrm{~kg} /$ 元 $\mathrm{k} l$ の仕込みにより, 全窒素 $2.441 \%$, 食塩 14.28\%の生酱油を得て, これより全窒素 $1.568 \%$, 食 塩 $9.25 \%$ の減塩奨油が得られる。なお, 掛原料として 膨化変性脱脂大豆を使用した場合の最終諸味粘度は $60 \mathrm{P}$ と高いが, 小麦グルテン使用の場合の諸味粘度は $32 \mathrm{P}$ と低くなる長所がある。

\section{9. 低汲水低塩仕込み法}

\section{（1）低汲水仕込みによる低塩奨油の製造}

9 水の低汲水仕込みにより, 全窒素 $2.01 \%$, 食塩 17.5\%の生滰油を得て, これから全窒素 $1.55 \%$ ・食塩 $13.5 \%$ の低塩奨油を製造できる。さらに，低汲水低塩 仕込みにすることにより，減塩奨油を製造できる ${ }^{20)}$ 。

（2）低汲水仕込みによる窒素利用率の低下と濃色化

9 水の低汲水仕込みには, 窒素利用率の低下, 濃色 化，諸味が硬くなる問題がある ${ }^{20)}$ 。

〈財)日本㽜油技術センター〉

\section{文献}

1）厚生労働省：平成 21 年度国民健康 ·栄養調査
結果の概要（2010）

2）厚生労働省：平成 17 年度国民健康 - 栄養調査 結果 (2006)

3）日本奨油協会, 全国奨油工業協同組合連合会, 日本槒油技術センター: 槒油の統計資料 (2009)

4) 田中秀夫：ジャパンフードサイエンス, 44 (10）, 40-46（1997）

5）田中秀夫：バイオサイエンスとインダストリー, 47, 614-617 (1989)

6）森本茂美，村上充代:醗工，43，828-835（1965）

7) 半谷吉識, 佐藤五雄, 下條 亮：再公表 WO2007/097374 (2007)

8）末澤保彦：醇協，105，(2），69-78（2010）

9）宮代龍次：香川発食試報, No.80, 37-39（1987）

10）浦 哲二, 佐々木正治, 稲森和夫, 古屋 武, 内田一生：奨研, 16, 200-205（1990）

11）花岡嘉夫：醗工, 45 ,22-28（1967）

12）浦 哲二, 稲森和夫, 古屋 武, 内田一生: 滰 研, 14, 187-205 (1988)

13）新国佐幸, 石山朋治, 鈴木千七, 鈴木忠直, 小 坂直治, 森 勝美: 食科工, 43, 910-916 (1996)

14）井部明広, 田端節子, 貞升友紀, 安井明子, 下 井俊子, 遠藤美代子, 斉藤和夫：食衛誌, 44, 220-226 (2003)

15）好井久雄：醸協，74，(4），213-218（1979）

16）伊藤 寛, 海老根英雄, 小坂正吉 : 食糧研報, No.18, 28-35 (1964)

17）増井正幹, 大西 博, 畒本 力: 好塩微生物, 314-315, 医歯薬出版 (1979)

18）今井誠一, 鈴木熊雄: 調味科学, 14 (4), 1-7 (1967)

19）関根悠太：私信

20）田中秀男，千葉秀雄：醸協，77，(11）, 767-771 (1982)

21） 宮崎桂一：特公昭 37-8543（1962）

22）織茂良和, 山崎達雄 : 特開 2005-245433（2005）

23）青沼辰雄, 安田 敦, 湯浅利純, 荒井 昇, 茂 木孝成，横塚 保：特公昭 49-43159（1974）

24）鈴木崇史, 大藤章一, 柴田義明：奨研, 5, 117120 (1979)

25）千葉秀雄：醸協，76，(1），18-21（1981）

26）馬場秀明, 馬場一之, 清水 毅, 木村延二郎： 㽜研，9，24-28（1983） 